\title{
HUBUNGAN MUTU PELAYANAN KESEHATAN DENGAN KEPUASAN PASIEN RAWAT JALAN DI PUSKESMAS SEI MENCIRIM MEDAN TAHUN 2020
}

\section{RIZKY ARDILLA LUBIS ${ }^{1}$, ANNISA DEWI PUTRI ${ }^{2}$, TARIANNA GINTING ${ }^{3}$, DAMERIA 4}

\author{
1,2,3,4 UNIVERSITAS PRIMA INDONESIA \\ JL. BELANGA NO.1, SEI PUTIH TENGAH, KEC. MEDAN PETISAH, KOTA \\ MEDAN, SUMATERA UTARA \\ e-mail : rizkylubis6@gmail.com
}

DOI : OI $10.35451 / j k f . v 3 i 1.467$

\begin{abstract}
The satisfaction problems that often arise in the Sei Mencirim Health Center Medan are inseparable from the services provided by the Health Center which are not good enough to cause patients to be dissatisfied with the services provided. Based on the results of research at the Sei Mencirim Health Center, Medan can be seen based on the level of patient satisfaction with timeliness having $40.5 \%$ good and $59.5 \%$ less good, based on empathy having $55.6 \%$ good and $44.4 \%$ less, and the environment has $20,7 \%$ is good and 79.3 is not good. This study aims to determine the relationship of timeliness, empathy, and the environment with the satisfaction of outpatients in the Sei Mencirim Health Center Medan. The study was an analytic survey using a cross sectional study design with a sample of 93 people. The sampling technique used is purposive sampling. The results of this study indicate that the $p$-values between timeliness $(0,000)$, empathy $(0,000)$, and the environment $(0,206)$. The results of multiple regression analysis prove that timeliness is significantly related to patient satisfaction. However, the most related to patient satisfaction is empathy compared to the Environment and significantly related to patient satisfaction. The conclusion is related to the timeliness and satisfaction of outpatients at the Sei Mencirim Health Center, while there is no environmental relationship with the satisfaction of the outpatients at the Sei Mencirim Health Center Medan.
\end{abstract}

Keywords: Timeliness, Empathy, Environment and Patient Satisfaction

\section{Pendahuluan}

Pelayanan publik merupakan tanggung jawab pemerintah dan dilaksanakan oleh instansi pemerintah, baik itu di pusat, di Daerah, dan dilingkungan Badan Usaha Milik Negara. Salah satu bentuk pelayanan publik yang dilaksanakan oleh pemerintah adalah pemenuhan kebutuhan kesehatan masyarakat.
Seperti yang tertuang dalam Keputusan Menteri Kesehatan Republik Indonesia No.951/Menkes/SK/VI/2000 yaitu bahwa tujuan pembangunan kesehatan adalah untuk meningkatkan kesadaran, kemauan dan kemampuan hidup sehat bagi setiap orang agar terwujud derajat kesehatan masyarakat yang optimal.

Pelayanan publik di bidang kesehatan dapat dilakukan Pusat 
Kesehatan Masyarakat (Puskesmas) di seluruh wilayah Indonesia. Peraturan Menteri Kesehatan Republik Indonesia nomor 75 tahun 2014 tentang Pusat Kesehatan Masyarakat (Puskesmas) adalah fasilitas pelayanan kesehatan yang menyelenggarakan upaya kesehatan masyarakat dan upaya kesehatan perseorangan tingkat pertama, dengan lebih mengutamakan upaya promotif dan preventif, untuk mencapai derajat kesehatan masyarakat yang setinggi-tingginya di wilayah kerjanya (Kementerian Kesehatan Republik Indonesia, 2014) Kebijakan dasar puskesmas disebutkan bahwa puskesmas merupakan tempat penyelenggara khusus dinas kesehatan kabupaten/kota yang memegang tanggung jawab menyelenggarakan jasa kesehatan tingkat pertama secara lengkap, teratur, serta berkelanjutan (Kemenkes RI No 128, 2004).

Terdapat 5 indikator kepuasaan pasien yaitu kenyataan (tangibles) berupa penampilan fasilitas fisik, kehandalan (reliability) berupa kemampuan petugas kesehatan dalam menangani masalah dengan cepat, tanggung jawab (responsivenes) berupa kesediaan petugas kesehatan dalam membantu pasien saat mengalami kesulitan, jaminan (assurance) berupa kemampuan dalam menjawab pertanyaan pasien perihal sakitnya, dan empati (emphaty) berupa perhatian kepada semua pasien (Nursalam, 2013).

Dari hasil penelitian Yutisia (2017) tentang Kualitas Pelayanan Puskesmas Dengan Kepuasan Pasien Lanjut Usia Di Puskesmas Mojowarno Jawa Timur memiliki pengaruh positif dan signifikan terhadap kepuasan pasien yaitu sebanyak 30 orang $(61,2 \%)$ lansia merasa puasa terhadap pelayanan yang diberikan.
Berdasarkan survei awal yang dilakukan peneliti di Puskesmas Sei Mencirim Medan pada Bulan Oktober 2019 data kunjungan di Puskesmas Sei Mencirim ada sebanyak 259 pasien yang di rawat inap atau opname, sedangkan pasien rawat jalan jumlah setiap bulannya naik turun. Jumlah kunjungan pasien rawat jalan mencapai 1250 kunjungan selama Januari Desember 2019. Saat ini jumlah petugas kesehatan yang ada di Puskesmas Sei Mencirim sebanyak 86 orang.

Hasil survei awal yang dilakukan dengan 10 pasien yang berkunjung ke Puskesmas Sei Mencirim Medan pada bulan Oktober 2019, peneliti melakukan wawancara terhadap 10 responden yang berkaitan dengan faktor-faktor yang mempengaruhi kepuasan, peneliti mendapatkan beberapa informasi dari 10 pasien mengenai tingkat kepuasan yang dirasakan pasien atau keluarga pasien berkaitan dengan pelayanan kesehatan yang diterimanya selama pemeriksaan di Puskesmas Sei Mencirim Medan. Adapun 8 orang $(80 \%)$ mengatakan bahwa mereka belum sepenuhnya puas dengan pelayanan kesehatan yang diberikan, diantaranya petugas kesehatan yang terlambat datang sehingga pasien harus menunggu lama, ruang antrian yang sempit serta masih banyak terdapat petugas kesehatan yang kurang ramah terhadap pasien. Sebanyak 2 orang (20\%) yang menyatakan puas terhadap pelayanan yang diberikan di bagian rawat inap alasannya yaitu petugas yang selalu aktif untuk mengontrol kondisi pasien.

\section{METODE}

Jenis penelitian adalah survey Analitik dengan menyebarkan kuesioner kepada responden yang merupakan sampel dalam penelitian ini. 
Rancangan penelitian ini yaitu dengan cross sectional suatu penelitian untuk mempelajari hubungan antara faktor yang beresiko dengan efek, dengan cara pendekatan, penilaian atau mangumpulkan data bertepatan pada suatu saat.

Cara pengumpulan data dalam penelitian ini adalah dengan cara membagikan kuesioner kepada para responden dan dengan mengambil data di puskesmas seperti data jumlah kunjungan pasien rawat jalan pada tahun 2020 di puskesmas sei mencirim.

Variabel bebas dalam penelitian ini adalah Ketapatan Waktu, Empati, Lingkungan dan Variabel Terikatnya adalah Kepuasan Pasien.

Populasi dalam penelitian adalah jumlah kunjungan pasien rawat jalan yang memeriksakan dirinya ke puskesmas di Bulan Januari Desember 2019 berjumlah 1250 orang, cara pengambilan sampel pada penelitian ini menggunakan Purposive Sampling, yaitu suatu cara pengambilan sampel dengan mempertimbangkan pemahaman atau pengetahuan responden terhadap materi penelitian sehingga didapatkan 93 orang sampel.

\section{HASIL}

Penelitian mengenai hubungan mutu pelayanan kesehatan dengan kepuasan pasien di puskesmas sei mencirim medan tahun 2020 berdasarkan ketepatan waktu dapat dilihat hasil tersebut dalam tabel 1 :
Tabel 1. Hubungan ketepatan waktu pelayanan kesehatan dengan kepuasan pasien rawat jalan di puskesmas sei mencirim medan tahun 2020

\begin{tabular}{|c|c|c|c|c|c|c|c|}
\hline \multirow[t]{3}{*}{$\begin{array}{l}\text { Ketepatan } \\
\text { waktu }\end{array}$} & \multicolumn{6}{|c|}{$\begin{array}{c}\text { Kepuasan Pasien Rawat } \\
\text { Jalan }\end{array}$} & \multirow[t]{3}{*}{$\begin{array}{c}P \\
\text { Value }\end{array}$} \\
\hline & \multicolumn{2}{|c|}{$\begin{array}{c}\text { Pasien } \\
\text { Puas }\end{array}$} & \multicolumn{2}{|c|}{$\begin{array}{c}\text { Pasien } \\
\text { Tidak } \\
\text { Puas }\end{array}$} & \multicolumn{2}{|r|}{ Tota } & \\
\hline & $\mathbf{N}$ & $\%$ & $\mathbf{n}$ & $\%$ & $\mathbf{N}$ & $\%$ & \\
\hline Baik & 15 & 40,5 & 22 & 59,5 & 37 & 100 & 0,000 \\
\hline Tidak baik & 2 & 3,6 & 54 & 96,4 & 56 & 100 & \\
\hline
\end{tabular}

Pada tabel 1 ditemukan bahwa 37 pasien rawat jalan yang menetapkan ketepatan waktu baik, mayoritas yang mengemukakan tidak puas berjumlah 22 orang $(59,5 \%)$ dan minoritas yang mengemukakan puas sebanyak 15 orang (40,5\%). Dari 56 pasien rawat jalan yang memilih ketepatan waktu tidak baik, mayoritas yang mengemukakan tidak puas berjumlah $54(96,4 \%)$ dan minoritas yang mengemukakan puas sebanyak 2 orang $(3,6 \%)$.

Hasil dari analisis bivariat dilakukan menggunakan uji chi square diperoleh angka $p$ value $=0,000(p$ value $<0,01)$, menyatakan Ho ditolak yang artinya ada hubungan yang signifikan dari ketepatan waktu dengan kepuasan pasien rawat jalan di puskesmas sei mencirim medan tahun 2020.

Penelitian mengenai hubungan mutu pelayanan kesehatan dengan kepuasan pasien di puskesmas sei mencirim medan tahun 2020 berdasarkan empati dapat dilihat hasil tersebut dalam tabel 2 .

Tabel 2. Hubungan Empati Pelayanan Kesehatan Dengan Kepuasan Pasien Rawat Jalan Di Puskesmas Sei Mencirim Medan Tahun 2020 


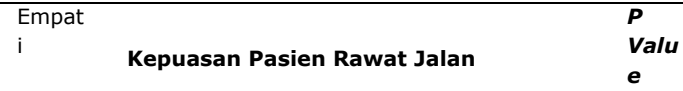

\begin{tabular}{|c|c|c|c|c|c|c|c|}
\hline & \multicolumn{2}{|c|}{ Puas } & \multicolumn{2}{|c|}{ Tidak Puas } & \multicolumn{2}{|c|}{ Total } & \\
\hline & $\mathbf{N}$ & $\%$ & $\mathbf{N}$ & $\%$ & $\mathbf{N}$ & $\%$ & \\
\hline Baik & 15 & 55,6 & 12 & 44,4 & 27 & 100 & 0,00 \\
\hline Tidak & & & & & & & 0 \\
\hline baik & 2 & 3 & 64 & 97 & 66 & 100 & \\
\hline
\end{tabular}

Pada tabel 2 tersebut ditemukan bahwa 27 pasien rawat jalan yang memilih empati baik, mayoritas yang mengemukakan puas sebanyak 15 responden $(55,6 \%)$ dan minoritas yang mengemukakan tidak puas sebanyak 12 responden (44,4\%). Dari 66 pasien rawat jalan yang menepatkan empati tidak baik, yang mengemukakan tidak puas sebanyak 64 (97\%) dan minoritas mengemukakan sebanyak 2 orang pasien (3\%).

Hasil dari analisis bivariat dilakukan menggunakan uji chi square diperoleh nilai $p$ value $=0,000$ ( $p$ value $<0,01)$, menyatakan Ho ditolak yang artinya ada hubungan yang signifikan antara empati dengan kepuasan pasien rawat jalan di Puskesmas Sei Mencirim Medan Tahun 2020.

Penelitian mengenai hubungan mutu pelayanan kesehatan dengan kepuasan pasien di puskesmas sei mencirim medan tahun 2020 berdasarkan lingkungan dapat dilihat hasil tersebut dalam tabel 3 :

Tabel 3. Hubungan Lingkungan Pelayanan Kesehatan Dengan Kepuasan Pasien Rawat Jalan Di Puskesmas Sei Mencirim Medan Tahun 2020

\begin{tabular}{|c|c|c|c|c|c|c|c|}
\hline \multirow[t]{3}{*}{ Lingkungan } & \multicolumn{6}{|c|}{ Kepuasan Pasien } & \multirow[t]{3}{*}{$\begin{array}{l}P \\
\text { Value }\end{array}$} \\
\hline & \multicolumn{2}{|c|}{ Puas } & \multicolumn{2}{|c|}{$\begin{array}{l}\text { Tidak } \\
\text { Puas }\end{array}$} & \multicolumn{2}{|c|}{ Total } & \\
\hline & $\mathbf{N}$ & $\%$ & $\mathbf{n}$ & $\%$ & $\mathbf{N}$ & $\%$ & \\
\hline Baik & 17 & 20 & 65 & 79 & 82 & 100 & 0,206 \\
\hline Tidak baik & 0 & 0 & 11 & 100 & 11 & 100 & \\
\hline
\end{tabular}

Pada tabel 3 tersebut ditemukan bahwa 82 pasien rawat jalan yang memilih lingkungan baik, mayoritas yang mengemukakan tidak puas sebanyak 65 responden $(79,3 \%)$ dan minoritas yang mengemukakan puas sebanyak 17 responden (20,7\%). Dan dari 11 pasien rawat jalan yang menepatkan lingkungan tidak baik, mayoritas yang mengemukakan tidak puas sebanyak $11 \quad(100 \%)$ dan minoritas mengemukakan puas tidak ada $(0 \%)$

Hasil analisis bivariat dilakuka menggunakan uji chi square diperoleh nilai $p$ value $=0,206$ ( $p$ value $>0,01)$, menyatakan Ha diterima yang artinya tidak ada hubungan yang signifikan antara lingkungan dengan kepuasan pasien rawat jalan di Puskesmas Sei Mencirim Medan Tahun 2020.

\section{PEMBAHASAN}

\section{Hubungan Ketepatan Waktu Pelayanan Kesehatan Dengan Kepuasan Pasien Rawat Inap Di Puskesmas Sei Mencirim Medan Tahun 2020}

Berdasarkan hasil uji statistik menggunakan uji chi-square diperoleh $p$ value $=0,000(p$ value $<0,01)$, artinya Ho ditolak ini sehingga dapat disimpulkan bahwa ada hubungan antara ketepatan waktu dengan kepuasan pasien rawat jalan di Puskesmas Sei Mencirim Medan Tahun 2020.

Hasil penelitian ini sejalan dengan penelitian Amelia (2018) di Puskesmas Paccerakang Kota Makasar yang menyatakan terdapat hubungan signifikan artinya ada hubungan antara ketepatan waktu dengan kepuasan pasien. Selanjutnya penelitian oleh Herman, et al (2013) Puskesmas Lembasada Kabupaten Donggala, menyatakan ada hubungan yang 
signifikan antara kualitas pelayanan ketepatan waktu dengan kepuasan pasien dengan hasil nilai $p=0,004$, yang berarti bahwa ketepatan waktu pelayanan kesehatan memiliki hubungan dengan kepuasan pasien rawat jalan di puskesmas.

\section{Berdasarkan} tabel menunjukkan antara mutu pelayanan berdasarkan ketepatan waktu layanan kesehatan, dari 37 responden memilih ketepatan waktu baik menyatakan puas sebanyak 15 orang $(40,5 \%)$. Hal ini dikarenakan responden tidak pernah menunggu lama saat mendapatkan pelayanan dari petugas kesehatan. Sedangkan responden memilih ketepatan waktu baik yang menyatakan tidak puas sebanyak 22 orang $(59,5 \%)$ responden. Hal ini dikarenakan dalam hal pelayanan administrsi sedikit berbelit-belit.

$$
\text { Dari } 56 \text { responden melilih }
$$

ketepatan waktu tidak baik menyatakan puas sebanyak 2 orang $(3,6 \%)$. Hal ini dikarenakan dengan karakteristik pendidikan SMP menganggap bahwa faktor ketepatan waktu tidak berpengaruh terhadap kepuasan mereka, serta masih dalam batas waktu yang wajar . sedangakan responden yang memilih ketepatan waktu tidak baik menyatakan tidak puas sebanyak 54 orang $(96,4 \%)$. Hal ini dikarenakan lamanya pelayanan yang diberikan petugas kesehatan dalam hal pelayanan administrasi \& pemberian obat, kehadiran dan kepulangan dokter serta petugas kesehatan yang tidak tepat waktu pada jam kerja puskesmas sei mencirim medan sehingga pasien harus menunggu dan pelayanan kepada pasien menjadi tertunda.

Secara teori yang mendukung penelitian ini, ketepatan waktu mempengaruhi keberhasikan mutu pelayanan, layanan kesehatan itu harus dilaksanakan dalam waktu dan cara yang tepat, oleh pemberi layanan yang tepat, dan menggunakan peralatan dan obat yang tepat, serta biaya yang efisien (Pohan, 2006).

Menurut asumsi peneliti bahwa ketepatan waktu baik karena responden kurang mengetahui ketepatan waktu yang telah ditetapkan sesuai dengan standart sehingga responden tidak menginginkan perubahan dalam hal ketepatan waktu yang diberikan oleh petugas kesehatan. Sedangkan responden dengan ketepatan waktu tidak baik karena responden mengetahui waktu yang sesuai dalam pemberian pelayanan sehingga mereka menginginkan perubahan ketepatan waktu layanan di puskesmas sei mencirim medan.

\section{Hubungan Empati Pelayanan Kesehatan Dengan Kepuasan Pasien Rawat Inap Di Puskesmas Sei Mencirim Medan Tahun 2020}

Berdasarkan hasil uji statistik menggunakan uji chi-square diperoleh $p$ value $=0,000(p$ value $<0,01)$, artinya Ho ditolak ini sehingga dapat disimpulkan bahwa ada hubungan antara empati dengan kepuasan pasien rawat jalan di Puskesmas Sei Mencirim Medan Tahun 2020.

Hasil penelitian ini sejalan dengan penelitian Halimatusa'diah (2015) yang menyatakan adanya hubungan yang signifikan antara persepsi pasien tentang empati pelayanan dengan minat pemanfaatan ulang rawat jalan di Puskesmas Ciputat Timur. Selanjutnya penelitian oleh Suparta, dkk (2018) di poli umum Puskesmas Lompoe Kota Pare-Pare, menyatakan ada hubungan yang signifikan antara empati dengan kepuasan pasien didapatkan nilai $\mathrm{p}=0,000$. Oleh karena $\mathrm{p}<(\mathrm{a})=0.01$ maka disimpulkan HO ditolak, yang artinya ada 
hubungan mutu pelayanan yang dilihat dari empati dengan kepuasan pasien di Poli Umum Puskesmas Lompoe Kota Pare-Pare.

Berdasarkan tabel 2.
menunjukkan antara mutu pelayanan berdasarkan empati layanan kesehatan, dari 27 responden memilih empati baik menyatakan puas sebanyak 15 orang $(55,6 \%)$. Hal ini dikarenakan responden merasakan kepedulian tenaga kesehatan dalam membantu setiap pasien membutuhkan. Sedangkan responden memilih empati baik menyatakan tidak puas sebanyak 12 orang $(44,4 \%)$ responden. Hal ini dikarenakan dalam hal petugas kesehatan kurang menyempurnakan pelayanan.

Dari 66 responden memilih empati tidak baik menyatakan puas sebanyak 2 orang (3\%). Hal ini dikarenakan puskesmas sei mencirim puskesmas terdekat dari tempat tinggal responden untuk mendapatkan pelayanan kesehatan. Sedangkan reponden memilih empati tidak baik menyatakan tidak puas sebanyak 64 orang (97\%). Hal ini dikarenakan responden merasa tidak puas dalam empati petugas kesehatan yang meliputi keramahan, kesopanan, kesabaran serta perhatian yang ditunjukkan petugas kesehatan dalam melayani pasien.

Berdasarkan teori yang mendukung penelitian ini dimana dimensi empati sangat berhubungan dengan kepuasan pasien karena empati perawat dapat membantu dalam kesembuhan pasien (Chunlaka,2010)

Menurut asumsi peneliti bahwa empati baik karena perhatian yang ditunjukkan oleh petugas kesehatan kepada pasien. Sedangkan empati tidak baik dengan kepuasan pasien kurang karena petugas kesehatan yang tidak ada perhatian seperi cuek, tidak ramah kepada pasien, serta petugas tidak memberikan pelayanan dengan sepenuh hati.

\section{Hubungan Lingkungan Pelayanan Kesehatan Dengan Kepuasan Pasien Rawat Inap Di Puskesmas Sei Mencirim Medan Tahun 2020}

Berdasarkan hasil uji statistik menggunakan uji chi square di peroleh nilai $p$ value $=0,206$ ( $p$ value $>0,01)$, artinya $\mathrm{Ha}$ diterima ini menunjukkan bahwa tidak ada hubungan yang signifikan antara lingkungan dengan kepuasan pasien rawat jalan di Puskesmas Sei Mencirim Medan Tahun 2020.

Hasil penelitian ini sejalan dengan penelitian Subekti (2009) di Puskesmas Kabupaten Tasikmalaya yang menyatakan tidak ada hubungan yang signifikan anatara lingkungan dengan kepuasan pasien dengan nilai $p$ value $=0,103>0,01$.

Secara teori yang mendukung dari penelitian ini, mempengaruhi keberhasikan mutu pelayanan dilihat dari kebersihan, keamanan dimana pasien yang berkunjung harus merasa aman dan nyaman saat berada di puskesmas (Pohan, 2006)

Dari 82 reponden yang memilih lingkungan baik menyatakan puas terdapat 17 orang $(20,7 \%)$. Hal ini dikarenakan lingkungan puskesmas sei mencirim yang bersih, rapi, serta memberikan rasa aman bagi pasien. Sedangkan responden yang memilih lingkungan baik yang menyatakan tidak puas sebanyak 65 orang $(79,3 \%)$. Hal ini dikarenakan keadaan ruang tunggu dipuskesmas kurang nyaman dengan situasi di sekitar ruang tunggu puskesmas.

Dari 11 responden yang memilih lingkungan tidak baik menyatakan puas sebanyak 0 , serta memilih lingkungan tidak baik menyatakan tidak puas 
sebanyak 11 orang (100\%). Hal ini dikarenakan tempat parkir sepeda motor yang sempit.

Berdasarkan teori yang mendukung penelitian ini, kepuasan pasien dipengaruhi oleh factor lingkungan internal ataupun ekternal, sehingga jika lingkungan yang diberikan kepada pasien maksimal makan kepuasan mereka juga akan meningkat (Wirawan,2009).

Menurut asumsi peneliti dikarenakan lingkungan puskesmas bersih, aman, dan teratur. Sedangkan lingkungan puskesmas tidak baik dikarenakan lingkungan yang kurang nyaman di wilayah puskesmas.

\section{KESIMPULAN}

Berlandaskan dari hasil penelitian mengenai hubungan mutu pelayanan kesehatan dengan kepuasan pasien rawat jalan di puskesmas sei mencirim medan tahun 2020, maka dapat peneliti menyimpulkan yaitu :

1. Untuk mengetahui hubungan mutu pelayanan kesehatan terhadap kepuasan pasien rawat jalan di Puskesmas Sei Mencirim Medan.

2. Terdapat hubungan mutu pelayanan kesehatan berlandaskan ketepatan waktu dengan kepuasan pasien rawat di Puskesmas Sei Mencirim Medan Tahun 2020.

3. Terdapat hubungan mutu pelayanan kesehatan berlandaskan empati dengan kepuasan pasien rawat di Puskesmas Sei Mencirim Medan Tahun 2020.

4. Tidak terdapat hubungan mutu pelayanan kesehatan berlandaskan lingkungan dengan kepuasan pasien rawat di Puskesmas Sei Mencirim Medan Tahun 2020.

\section{DAFTAR PUSTAKA}

Amelia, I. (2018), Faktor Yang Berhubungan Dengan Mutu
Pelayanan Kesehatan Terhadap Kepuasan Pasien BPJS Rawat Jalan Puskesmas Paccerakang Kota Makassar, p. 3.

Cunlaka, poramaphon, internasional patients satisfaction toward nurses sevice quality. 2010

Herman, Sudirman and Nizmayanun (2013) Hubungan kualitas pelayanan kesehatan dengan kepuasan pasien rawat jalan di puskesmas lembasada kabupaten donggala. Journal of Petrology, 369(1), pp. 1689-1699. doi: 10.1017/CBO9781107415324.004.

Halimatusa'diah (2015) Hubungan Persepsi Pasien Terhadap Mutu Pelayanan Dengan Minat Pemanfaatan Ulang Rawat Jalan Umum Di Puskesmas Ciputat Timur Tahun 2015. pp. 1-141.

Kesehatan, T., Peraturan, D. A. N. and Berencana, D. A. N. K. (2013) Kajian Undang-Undang Nomor 36 Tahun 2009 Tentang Kesehatan dan Peraturan Perundang-undangan Lain Terkait Hak Kesehatan Reproduksi dan Keluarga Berencana. Buletin Penelitian Sistem Kesehatan.

Nursalam (2013) Metodologi Penelitian IImu Keperawatan: Pendekatan Praktis. 3rd edn. Jakarta: Medika Salemba.

Pohan, I. (2017) Manajemen Kepuasan Pelanggan. Vol 3. Jakarta: Salemba Medika.

Pohan, I. S. (2006) jaminan mutu pelayanan kesehatan: Dasar Dasar Pengertian Dan Penerapan. Jakarta: EGC.

Suparta, Haryono and Kamsir, A. (2018) Hubungan Mutu Pelayanan Terhadap Kepuasan Pasien Di Poli Umum Puskesmas Lompoe Kota Pare-Pare. Jurnal IImiah Kesehatan Pencerah.

Subekti, D. (2009) tingkat kepuasan pasien balai pengobatan umum puskesmas di kabupaten pengesahan tesis balai pengobatan (bp) umum puskesmas di kabupaten tasikmalaya tahun 2009, Universitas Diponogoro. Universitas Diponegoro Semarang.

Wirawan,2009, Evaluasi Kinirja, SDM, 
Teori, Aplikasi dan Penelitian.

Jakarta : PT. Rajagrafindo.Persada.

Yustisia, B. (2017) Kualitas Pelayanan

Puskesmas Dengan Kepuasan

Pasien Lanjut Usia. STIK Jombang,

pp. 1-136. Available at:

http://repository.uinjkt.ac.id/dspac

e/bitstream/123456789/37953/1/RI

ZQIANA ADAWIYAH-FKIK.pdf 